
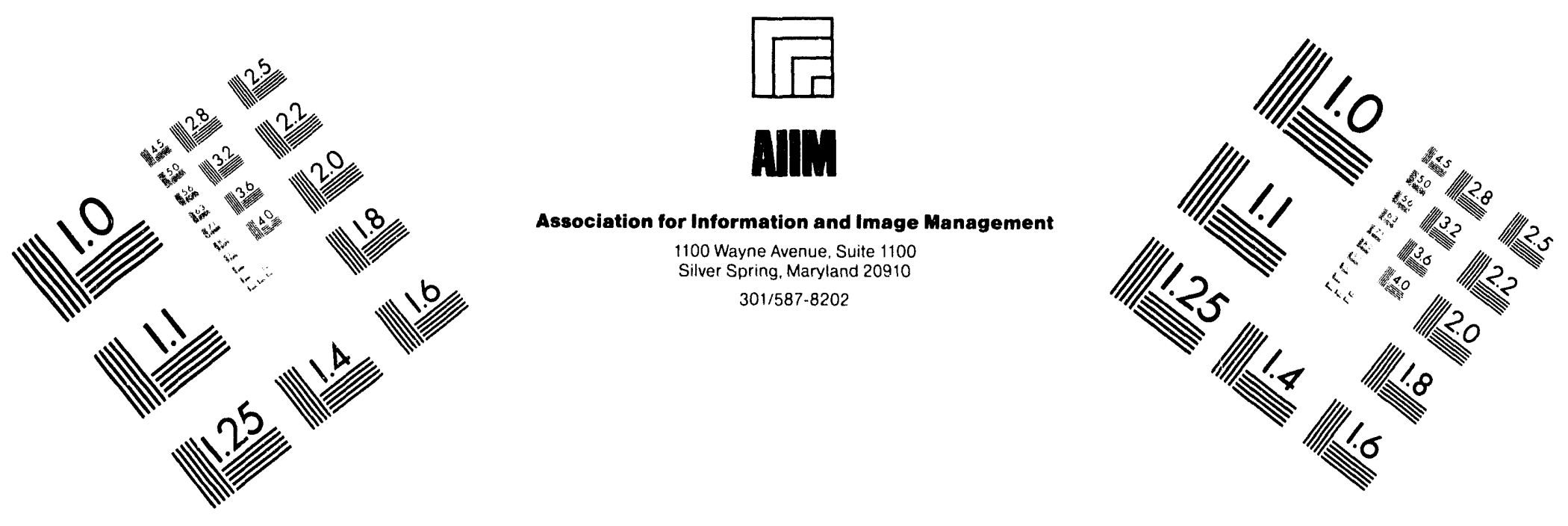

\title{
Centimeter
}

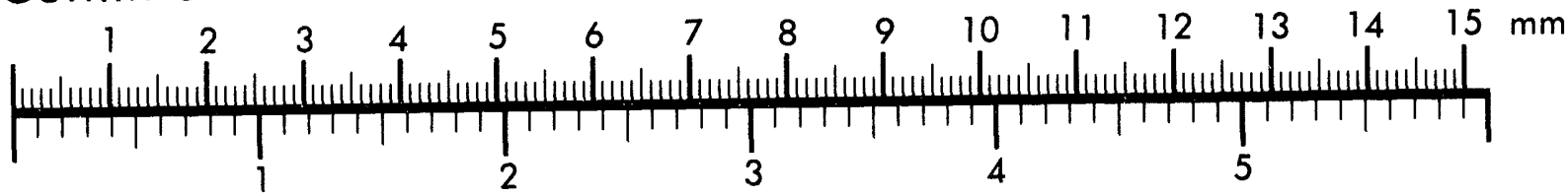

Inches
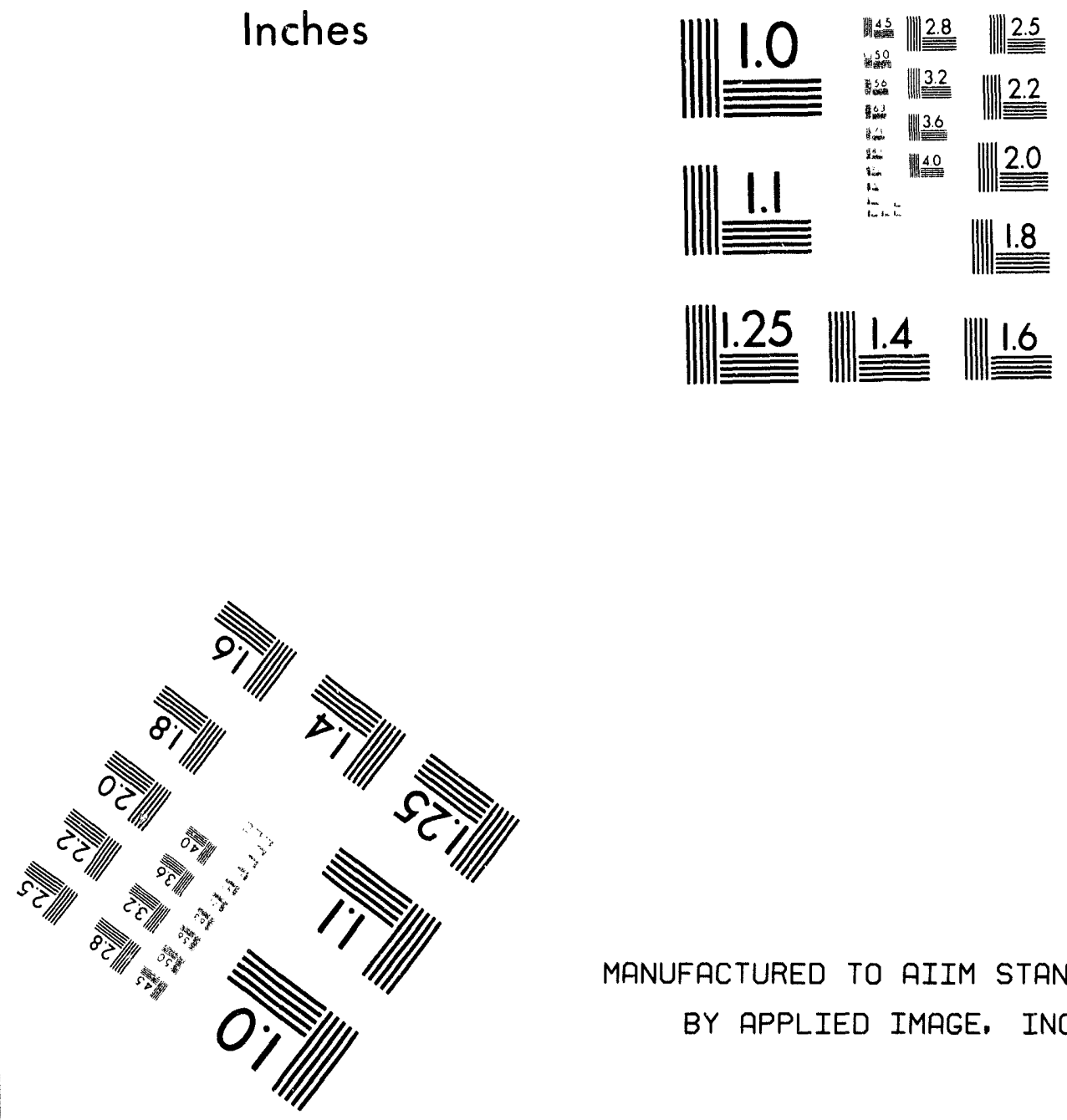

MANUFACTURED TO AIIM STANDARDS

BY APPLIED IMAGE, INC.

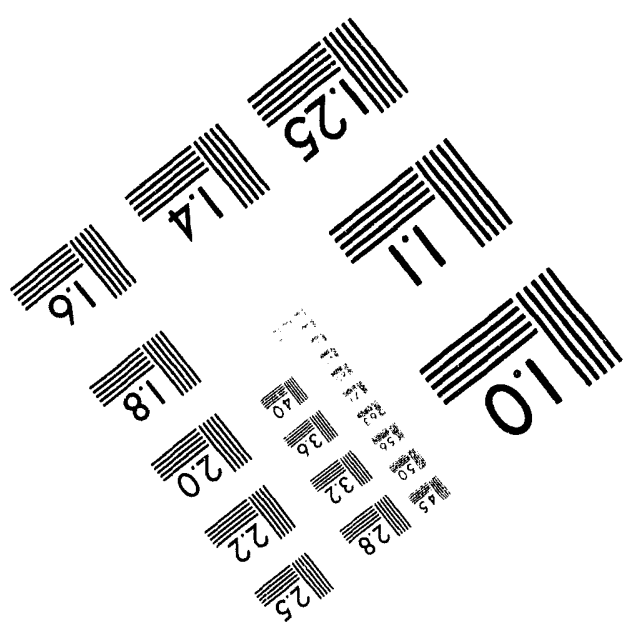



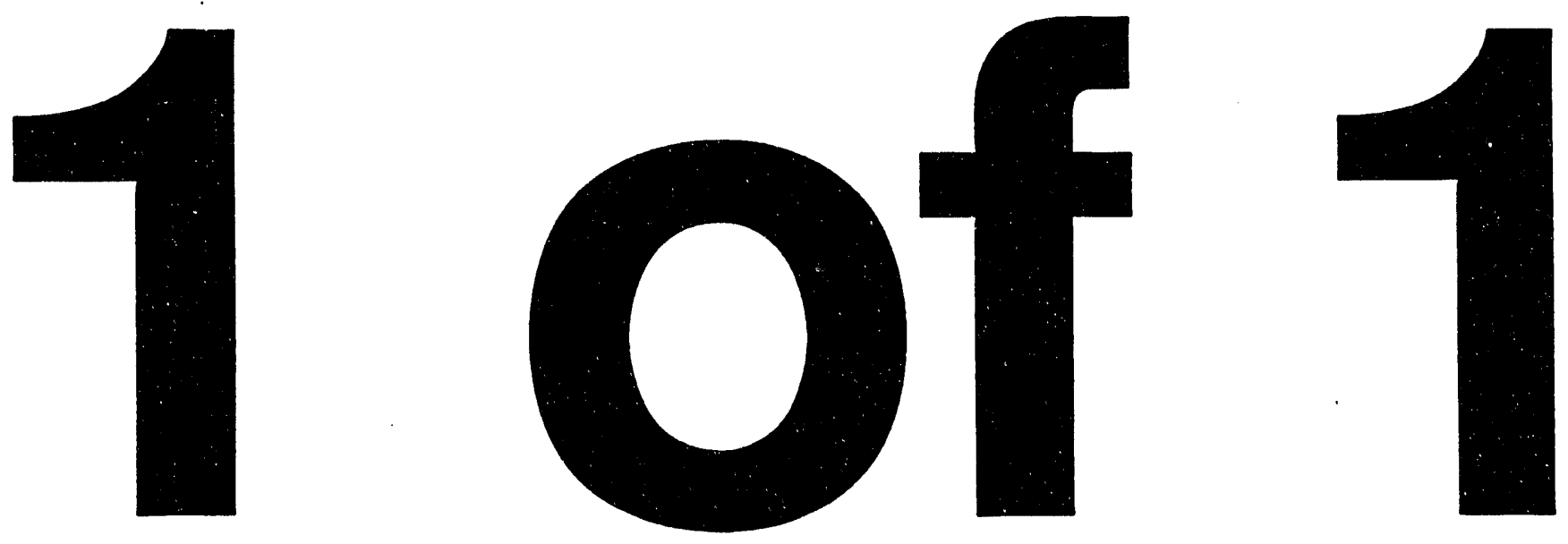


\title{
DOE/PC/198/8- - TII
}

\section{BENCH-SCALE CO-PROCESSING}

Contract No. DE-AC22-87PC79818

Technical Progress Report No. 22 (10/01/93-12/31/93)

by

\author{
M.L.M. Duttlinger, S.E. Commisaris, L.A. Davis, R.W. Yurek, \\ J.G. Gatsis, R. Roemisch and M. Kojima \\ UOP \\ 25 East Algonquin Road \\ Des Plaines, IL 60017-5017
}

\begin{abstract}
UOP's second co-processing contract, DE-AC22-87PC79818, began in April 1988. The major objective of this contract is to establish a database for the optimization of the co-processing concept by improving the effectiveness of the co-processing catalyst system. Two major mechanisms for improving the catalyst system are to be investigated: employment of more effective catalysts and utilization of improved catalytic environments. These two mechanisms are defined in the contract Statement of Work under Task 3.2 as Subtask 3.2 .1 and 3.2 .2 , respectively.
\end{abstract}

This report covers the period of October 1, 1993 to December 31, 1993. During this period work on Subtask 3.2.2, Improvement in Catalytic Environment, was carried out and the bench-scale co-processing pilot plant was operated in the co-current mode with product recycle and increased catalyst concentration. The project objective was to achieve $90+\%$ conversion of the $510^{\circ} \mathrm{C}+$ non-distillables at 2800 psig. Currently work is on-going in a stirred autoclave at the same catalyst concentration as that in the runs reported here, and the results of these autoclave runs will be summarized in Technical Progress Report No. 23.

\section{EXPERIMENTAL}

\section{Feedstock}

Lloydminster vacuum resid (R10, UOP 58-1625) was used as the feed for Pilot Plant 558 co-current Aurabon runs. For the two runs discussed in this report, no coal was added to the feed. The vacuum resid was obtained from Husky Oil Lloydminster Refinery in May, 1988. The properties of the feedstock are presented in Table 1. The feed has an API of 6.6 with $82 \mathrm{wt} \%$ of the feed boiling above $510^{\circ} \mathrm{C}$. The feed contains $4.8 \mathrm{wt} \%$ sulfur, $0.6 \mathrm{wt} \%$ nitrogen, $13.6 \mathrm{wt} \%$ heptane insoluble and $17.4 \mathrm{wt} \%$ microcarbon residue.

\section{Pilot Plant Testing}

Two runs, Run 42 and 43, were conducted in Pilot Plant 558, a schematic diagram of which is shown in Figure 1. In both runs, Lloydminster vacuum resid spiked with $0.5 \mathrm{wt} \%$ Mo present as a slurry-phase catalyst was processed. Operating conditions for Runs 42 and 43 can be viewed in Tables 2 and 3 , respectively. Plant outlet pressure was maintained at 2800 psig except during plant upsets. The target

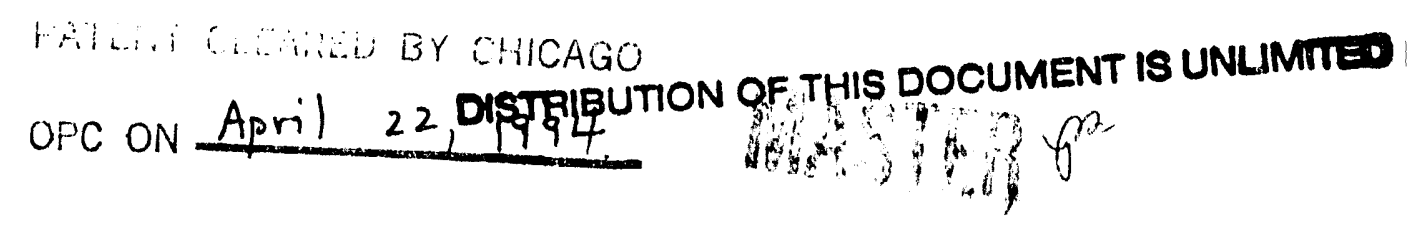


fresh feed rate was 0.5 liquid hourly space velocity (LHSV), where LHSV was defined as (cc fresh feed per hour) $/$ (cc reactor volume). The reactor temperature ranged from $350^{\circ} \mathrm{C}$ to $470^{\circ} \mathrm{C}$.

The feed was pumped upflow into the reactor. A slip stream was taken off the high pressure separator (HPS) bottoms to maintain a constant level in the HPS which was held at $125^{\circ} \mathrm{C}$ and $2500 \mathrm{psig}$. The rest of the HPS bottoms was recycled back to the reactor unless indicated otherwise. The recycle to feed ratio varied between 0 and 12:1. The slip stream was taken into a low pressure stripper (LPS) where the light ends were stripped off at $135^{\circ} \mathrm{C}$ and 50 psig by an upflow $\mathrm{N}_{2}$ stream. The HPS off-gas was taken into a three-phase separator where it was contacted with water, removing any salts which were contained in the partially condensed HPS off-gas. The hydrocarbon from the three-phase separator was sent to the debutanizer column.

The three-phase off-gas was recycled back to the reactor. It was mixed with fresh $\mathrm{H}_{2}$ and fed upflow into the reactor. Some of the three-phase off-gas was bled off to maintain a hydrogen purity of approximately $90 \mathrm{~mol} \%$. The LPS bottoms product was collected in a container kept in a hot box. The debutanizer column bottoms were collected while the overhead gas was measured and vented.

\section{Operations}

\section{Run 42}

Run 42 was started up in the once-through mode with a fresh feed rate of 0.5 LHSV. Plant pressure was 2800 psig and the reactor block temperatures were set to obtain an internal average bed temperature (ABT) of $420^{\circ} \mathrm{C}$. The gas recycle rates were set to obtain $9000 \mathrm{SCFB}(6.9 \mathrm{SCFH}) \mathrm{H}_{2}$ to the reactor and $6000 \mathrm{SCFB}$ (4.6 SCFH) $\mathrm{H}_{2}$ to feed. A summary of the run operating conditions for period 1 is given in Table 2.

After 8 hours on stream (HOS), an exotherm was detected in the reactor bed. The temperatures rose to $440^{\circ} \mathrm{C}$ at $13^{\prime \prime}$ above the reactor inlet. The reactor temperature was lowered in an attempt to eliminate this exotherm. While the magnitude of the maximum bed temperature decreased, the exotherm remained. The run was aborted at 26 HOS when a plug developed in the reactor. This plug caused a 200 psia pressure differential to appear across the reactor which could not be cleared.

\section{$\underline{\text { Run } 43}$}

Run 43 was also started up in the once-through mode with plans to establish HPS recycle to feed once levels were established. Plant pressure, fresh feed rate and gas recycle rates were set at $2800 \mathrm{psig}, 0.5$ LHSV, and 9000 SCFB (6.9 SCFH) $\mathrm{H}_{2}$ to the reactor/6000 SCFR (4.6 SCFH) $\mathrm{H}_{2}$ to feed, respectively, as in Run 42. On account of exotherms observed in Run 42, an initial average bed temperature (ABT) of $400^{\circ} \mathrm{C}$ was targeted. Summary of the run operating conditions and pilot plant log sheets beginning with period 4 (48 to $60 \mathrm{HOS}$ ) are given in Tables 3 and 4, respectively. During the line-cut period (7 HOS), a 100 psia pressure differential appeared across the reactor. This was cleared by increasing the gas recycle rates and cutting out the make-up $\mathrm{H}_{2}$. A second plug developed at $10.5 \mathrm{HOS}$ and was also cleared with increased gas recycle rates.

Recycle was established at 15.5 HOS (period 1). The HPS level and recycle to feed were lost at 16 HOS. The reactor temperatures were lowered to avoid coking in the reactor. A pressure differential appeared across the reactor which cleared itself when it reached 700 psia. At 22 HOS (period 1), the plant 
pressure fell to $2650 \mathrm{psig}$.

Recycle was re-established during period 2, at which point the temperature of one of the furnace blocks controlling the preheater was increased by $5^{\circ} \mathrm{C}$. A plug began to develop at $39.5 \mathrm{HOS}$ (period 3) and was cleared by increasing the recycle rate and cutting out the fresh feed.

The plant operations stabilized and the ABT was increased to $410^{\circ} \mathrm{C}$ at $49.5 \mathrm{HOS}$ (period 4). The ABT did not become steady but instead cycled between 405 and $415^{\circ} \mathrm{C}$.

Another 700 psia pressure differential developed across the reactor at $70 \mathrm{HOS}$ (period 5) which cleared itself within 5 minutes. After the plug cleared, the HPS level decreased and recycle was lost. At 72 HOS (period 5), the recycle line to the reactor and the reactor itself plugged. Both were cleared by 73 HOS (period 5). The recycle rate was increased to a recycle to fresh feed ratio of 20:1 to make sure that the rcactor and recycle line plugs were cleared. The ABT continued to cycle during periods 6 and 7 .

At $100.5 \mathrm{HOS}$, the $\mathrm{ABT}$ was increased to $425^{\circ} \mathrm{C}$. Thirty minutes later $(101 \mathrm{HOS}$, period 8 ), a 50 psia pressure differential appeared across the reactor. The recycle gas rates were tripled in an attempt to clear the plug before it became too large. This caused the plant pressure to increase to $3100 \mathrm{psig}$. When the plug cleared at $113 \mathrm{HOS}$ (period 9), the plant and reactor pressures equilibrated at $2900 \mathrm{psig}$. The excess recycle gas (ERG) drag was increased to bring the pressure down to $2800 \mathrm{psig}$. The pressure upset caused the HPS level to fall to 13 ma (i.e., near empty) and recycle was momentarily lost.

At $126 \mathrm{HOS}$ (period 10), the reactor temperature suddenly increased to $420^{\circ} \mathrm{C}$ and was cycling during periods 10 and 11. At $154 \mathrm{HOS}$ (period 12), the reactor temperature rose again and recycle was lost. All reactor temperatures were decreased to $420^{\circ} \mathrm{C}$ and recycle gas rates were increased. A small plug developed at 157 HOS (period 13) which was easily cleared. Recycle was re-established at 161 HOS (period 13) at a recycle to fresh feed ratio of 10:1 and recycle gas rates were decreased to original specifications. Reactor temperatures were increased during period 14 once operations were stabilized.

The plant was producing only $15 \%$ overhead (material to the debutanizer column) at $182 \mathrm{HOS}$; the furnace block temperatures were therefore increased by $5^{\circ} \mathrm{C}$. This caused an immediate exotherm to develop. To reduce the exotherm, the recycle rate was increased. At this point, it was decided that having preheater furnace block temperatures exceeding $500^{\circ} \mathrm{C}$ in order to achieve an isothermal bed temperature profile was not desirable. Reactor temperatures would be adjusted to maintain a constant maximum bed temperature and the temperature differential across the reactor would be monitored. The maximum temperature targeted was $440^{\circ} \mathrm{C}$.

At $204 \mathrm{HOS}$ (period 17), the maximum bed temperature rose to $450^{\circ} \mathrm{C}$. It was decided that as long as the temperature remained near or below $450^{\circ} \mathrm{C}$, no adjustments would be made. At $215 \mathrm{HOS}$ (period 17), a plug began developing across the reactor. The pressure differential was approximately 70 psia. As the pressure differential increased (period 18), the preheater temperature was decreased by $5^{\circ} \mathrm{C}$ and the recycle rate was increased. At $229.5 \mathrm{HOS}$ (period 19), the maximum bed temperature dropped to $434^{\circ} \mathrm{C}$.

The pressure differential across the reactor was 100 psia at $265 \mathrm{HOS}$ (period 22) and the maximum bed temperature was $450^{\circ} \mathrm{C}$. Preheater temperatures were lowered to try to lower the bed temperature. At $290 \mathrm{HOS}$, the pressure differential increased to 400 psia and the run was terminated.

Figures 2 and 3 plot temperature profiles at different hours on stream. The legends indicate the furnace 
block temperatures. Two furnace blocks controlled the preheater, and the reactor portion was controlled by two separate blocks. The block controlling the inlet portion of the reactor is designated as "In" and that controlling the outlet portion of the reactor is designated as "Out" in the figures. As Figure 2 illustrates, for virtually constant furnace block temperatures, the reactor temperature profile varied by as much as $15^{\circ} \mathrm{C}$ above $2^{\prime \prime}$ from the inlet, and nearly $40^{\circ} \mathrm{C}$ at the inlet. Figure 3 shows that increasing all the furnace block temperature settings by $5^{\circ} \mathrm{C}$ raised the reactor temperature by 30 to $60^{\circ} \mathrm{C}$. Lowering the preheater block temperatures to $475^{\circ} \mathrm{C}$ resulted in a $80^{\circ} \mathrm{C}$ gradient across the reactor.

\section{RESULTS AND DISCUSSION}

No analysis was taken of the product from Run 42 . The run was aborted before the plant was lined out. The restriction in the reactor was approximately $4.5^{\prime \prime}$ long and started $16^{\prime \prime}$ above the preheater (10" from the top of the reactor). The plug was solid and could not be dissolved in toluene. The restriction had to be drilled out. The exotherm observed at the beginning of the run is consistent with having $0.5 \mathrm{wt} \%$ Mo in the feed. It is well known that Mo is one of the most active catalysts for heavy resid conversion (RBearden and CLAldridge, AIChE 90th National Meeting, 1981).

In spite of starting Run 43 with an $\mathrm{ABT}$ of $400^{\circ} \mathrm{C}$, it was not possible to eliminate exotherms. Moreover, throughout Run 43 development of hot spots was observed. This suggests that the catalyst distribution in the reactor might not have been uniform. Pockets of catalyst starvation and development of hot spots are likely to lead to plugging, which occurred frequently in Run 43. It was extremely difficult to control the reactor temperature in this run. Aside from exotherms and development of hot spots, reactor temperatures varied erratically when the furnace block temperatures, feed rate and gas rates were held essentially constant.

Product samples from periods 15 and 20 in Run 43 were analyzed and the results are summarized in Table 5. The conversion levels were comparable in the two periods and were low. While the ABT in period 15 was $427^{\circ} \mathrm{C}$, because of the size of the inventory in the plant, the product collected in period 15 was more likely produced in earlier periods, where the ABT was much lower $\left(399^{\circ} \mathrm{C}\right.$ in period 13 and $412^{\circ} \mathrm{C}$ in period 14 ). Similarly the product produced in period 20 was most likely produced in periods 18 and 19 when the ABT was 417 and $401^{\circ} \mathrm{C}$, respectively. Clearly, overall conversion is a larger function of temperature than catalyst concentration. As a result of carrying out resid conversion at low reactor temperatures, gas make and coke make were also low. Asphaltene (heptane insoluble) conversion was considerably higher than the $510^{\circ} \mathrm{C}+$ conversion, and this suggests that asphaltene conversion is more readily effected in the presence of catalyst, whereas overall resid conversion is primarily governed by temperature.

Run 43 was aborted at 290 HOS. Upon unloading the reactor a restriction was found, deposited approximately 1 " above the preheater and $1.5^{\prime \prime}$ in length. The solid deposits were found to consist of $76.9 \mathrm{wt} \% \mathrm{C}, 3.5 \% \mathrm{H}, 8.0 \% \mathrm{~S}$ and $7.3 \% \mathrm{Mo}$, suggesting that there was some catalyst accumulation in the reactor, and further that there was considerable coking. Product recycle could in part account for plugging, as no attempt was made to remove coke pre-cursors from the recycle stream and they were recycled together with unconverted feed.

Difficulties encountered in controlling the reactor temperature suggest that the liquid flow characteristics in the reactor were such that there was little back-mixing. The superficial gas velocity at $15000 \mathrm{SCFB}$ of $\mathrm{H}_{2}$ is $0.27 \mathrm{~cm} / \mathrm{s}$, while the superficial liquid velocity at a recycle ratio of $10: 1$ is $0.08 \mathrm{~cm} / \mathrm{s}$. Commercially, the superficial gas velocity is expected to fall in the range $3-8 \mathrm{~cm} / \mathrm{s}$, where much greater back-mixing is likely to be achieved, but where foaming becomes a serious problem. At the flow rates 
employed in Run 43, it is most unlikely that there was any foaming. At the same time, it appears that there was not nearly as much back-mixing as needed, particularly in the presence of a very active catalyst where hot spots can easily develop unless the catalyst is very uniformly distributed in an isothermal reactor.

\section{DISCLAIMER}

This report was prepared as an account of work sponsored by an agency of the United States Government. Neither the United States Government nor any agency thereof, nor any of their employees, makes any warranty, express or implied, or assumes any legal liability or responsibility for the accuracy, completeness, or usefulness of any information, apparatus, product, or process disclosed, or represents that its use would not infringe privately owned rights. Reference herein to any specific commercial product, process, or service by trade name, trademark, manufacturer, or otherwise does not necessarily constitute or imply its endorsement, recommendation, or favoring by the United States Government or any agency thereof. The views and opinions of authors expressed herein do not necessarily state or reflect those of the United States Government or any agency thereof. 
Table 1

Feed Analysis

Analysis of Lloydminster Vacuum Redid

UOP 58-1625

\begin{tabular}{||c|c|}
\hline API Gravity & 6.6 \\
Specific Gravity & 1.0246 \\
\hline Distillation, ${ }^{\circ} \mathrm{C}$ & \\
IBP & 379 \\
5 & 455 \\
10 & 473 \\
20 & 509 \\
EP & 512 \\
$\%$ EP & 22 \\
$\% 510^{\circ} \mathrm{C}$ & 82 \\
\hline C wt $\%$ & 83.6 \\
H wt\% & 10.3 \\
S wt $\%$ & 4.8 \\
N wt\% & 0.6 \\
MCRT wt $\%$ & 17.4 \\
C $_{7}$ Insol wt $\%$ & 13.6 \\
Ni ppm & 82 \\
V ppm & 183 \\
Pour Point, ${ }^{\circ} \mathrm{C}$ & 54 \\
\hline
\end{tabular}


Table 2 : Run 42 Operating Conditions

\begin{tabular}{|c|c|c|c|c|c|c|c||}
\hline Period & $\begin{array}{c}\text { FF Rate } \\
\text { LHSV }\end{array}$ & $\begin{array}{c}\text { Rec to } \\
\mathrm{FF} \\
\text { Ratio }\end{array}$ & $\begin{array}{c}\mathrm{H}_{2} \text { Drag } \\
\mathrm{cf} / \mathrm{hr}\end{array}$ & $\begin{array}{c}\mathrm{H}_{2} \text { to } \\
\mathrm{Rx} \\
\mathrm{SCFH}\end{array}$ & $\begin{array}{c}\mathrm{H}_{2} \text { to } \\
\text { Feed } \\
\text { SCFH }\end{array}$ & $\begin{array}{c}\text { Plant } \\
\text { Press } \\
\text { psig }\end{array}$ & $\begin{array}{c}\text { Rx Internal } \\
\text { ABT }\left({ }^{\circ} \mathrm{C}\right)\end{array}$ \\
\hline 1 & 0.48 & 0 & 2.0 & 8.2 & 5.0 & 2800 & 421 \\
\hline
\end{tabular}

Table 3 : Run 43 Operating Conditions

\begin{tabular}{|c|c|c|c|c|c|c|c|c|}
\hline Period & $\begin{array}{c}\text { FF Rate } \\
\text { LHSV }\end{array}$ & $\begin{array}{l}\text { Rec to } \\
\text { FF } \\
\text { Ratio } \\
\end{array}$ & $\begin{array}{c}\mathrm{H}_{2} \text { Drag } \\
\mathrm{cf} / \mathrm{hr}\end{array}$ & $\begin{array}{l}\mathrm{H}_{2} \text { to } \\
\text { Feed } \\
\text { SCFH }\end{array}$ & $\begin{array}{c}\mathrm{H}_{2} \text { to } \\
\mathrm{Rx} \\
\text { SCFH }\end{array}$ & $\begin{array}{l}\text { Plant } \\
\text { Press } \\
\text { psig } \\
\end{array}$ & $\begin{array}{c}\mathrm{Rx} \\
\text { Internal } \\
\mathrm{ABT}{ }^{\circ} \mathrm{C}\end{array}$ & $\begin{array}{c}\text { Max } \\
\text { Temp } \\
{ }^{\circ} \mathrm{C}\end{array}$ \\
\hline 4 & 0.59 & 3.5 & 0.63 & 8.6 & 11.7 & 2800 & 409 & 414 \\
\hline 5 & 0.46 & 4.0 & 0.56 & 8.7 & 13.5 & 2800 & 411 & 418 \\
\hline 6 & 0.46 & 8.5 & 0.48 & 9.9 & 13.4 & 2800 & 397 & 416 \\
\hline 7 & 0.51 & 6.6 & 0.63 & 9.8 & 12.1 & 2800 & 408 & 423 \\
\hline 8 & 0.52 & 6.6 & 0.59 & 11.1 & 14.9 & 2800 & 415 & 429 \\
\hline 9 & 0.48 & 7.3 & 0.52 & 9.8 & 12.8 & 2800 & 416 & 421 \\
\hline 10 & 0.51 & 6.7 & 0.58 & 9.3 & 12.2 & 2800 & 409 & 417 \\
\hline 11 & 0.50 & 6.8 & 0.50 & 9.4 & 12.5 & 2800 & 412 & 425 \\
\hline 12 & 0.54 & 5.9 & 0.59 & 9.6 & 13.8 & 2800 & 416 & 430 \\
\hline 13 & 0.74 & 1.7 & 0.50 & 21.5 & 38.9 & 2800 & 399 & 411 \\
\hline 14 & 0.54 & 10.0 & 0.56 & 9.3 & 15.9 & 2800 & 412 & 434 \\
\hline 15 & 0.49 & 10.8 & 0.54 & 9.2 & 15.3 & 2800 & 427 & 460 \\
\hline 16 & 0.50 & 10.2 & 0.48 & 9.6 & 14.5 & 2800 & 410 & 439 \\
\hline 17 & 0.50 & 10.2 & 0.50 & 9.1 & 14.9 & 2800 & 422 & 444 \\
\hline 18 & 0.53 & 9.7 & 0.54 & 12.1 & 22.6 & 2800 & 417 & 441 \\
\hline 19 & 0.46 & 10.9 & 0.55 & 9.2 & 15.1 & 2800 & 401 & 441 \\
\hline 20 & 0.48 & 10.5 & 0.58 & 9.6 & 16.0 & 2800 & 411 & 442 \\
\hline 21 & 0.43 & 11.5 & 0.59 & 9.7 & 16.6 & 2800 & 410 & 442 \\
\hline 22 & 0.56 & 8.7 & 0.79 & 9.2 & 16.0 & 2800 & 424 & 443 \\
\hline 23 & 0.46 & 10.7 & 0.79 & 9.5 & 15.2 & 2800 & 426 & 451 \\
\hline
\end{tabular}


Table 5

Plant 558 Run 43

\begin{tabular}{|c|c|c|}
\hline Period & 15 & 20 \\
\hline \hline ABT $\left({ }^{\circ} \mathrm{C}\right)$ & 427 & 411 \\
\hline $510^{\circ} \mathrm{C}+$ conversion & $34 \%$ & $35 \%$ \\
\hline Heptane insoluble conversion & $57 \%$ & $56 \%$ \\
\hline $\begin{array}{c}\text { Microcarbon residue } \\
\text { conversion }\end{array}$ & $30 \%$ & $29 \%$ \\
\hline $\begin{array}{c}\text { Sulfur removal } \\
\text { Nitrogen removal }\end{array}$ & $57 \%$ & $58 \%$ \\
\hline Wt $\%$ coke yield & $0.7 \%$ & $59 \%$ \\
\hline Wt\% $\mathrm{C}_{1}-\mathrm{C}_{4}$ yield & $2.3 \%$ & $3.3 \%$ \\
\hline
\end{tabular}




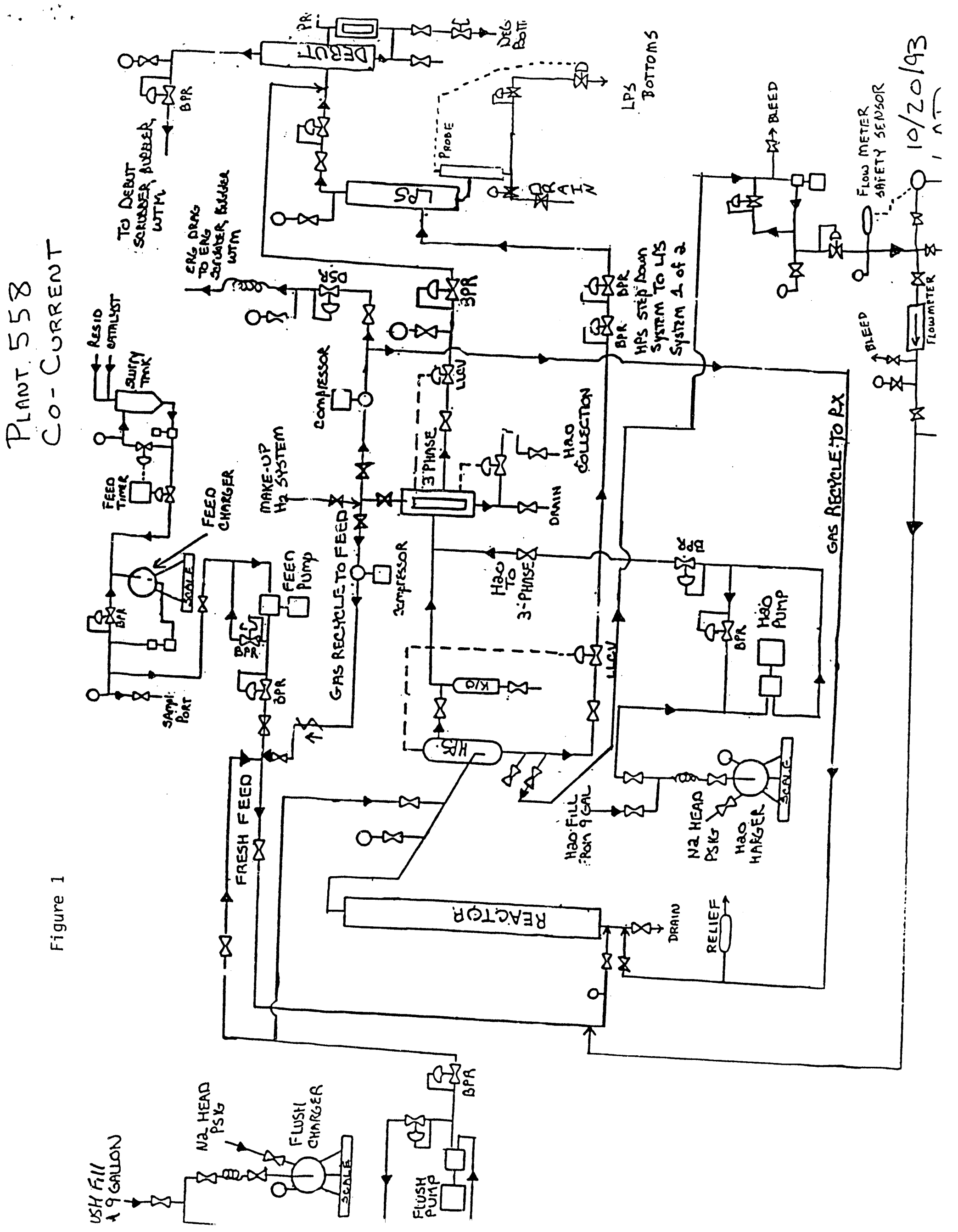



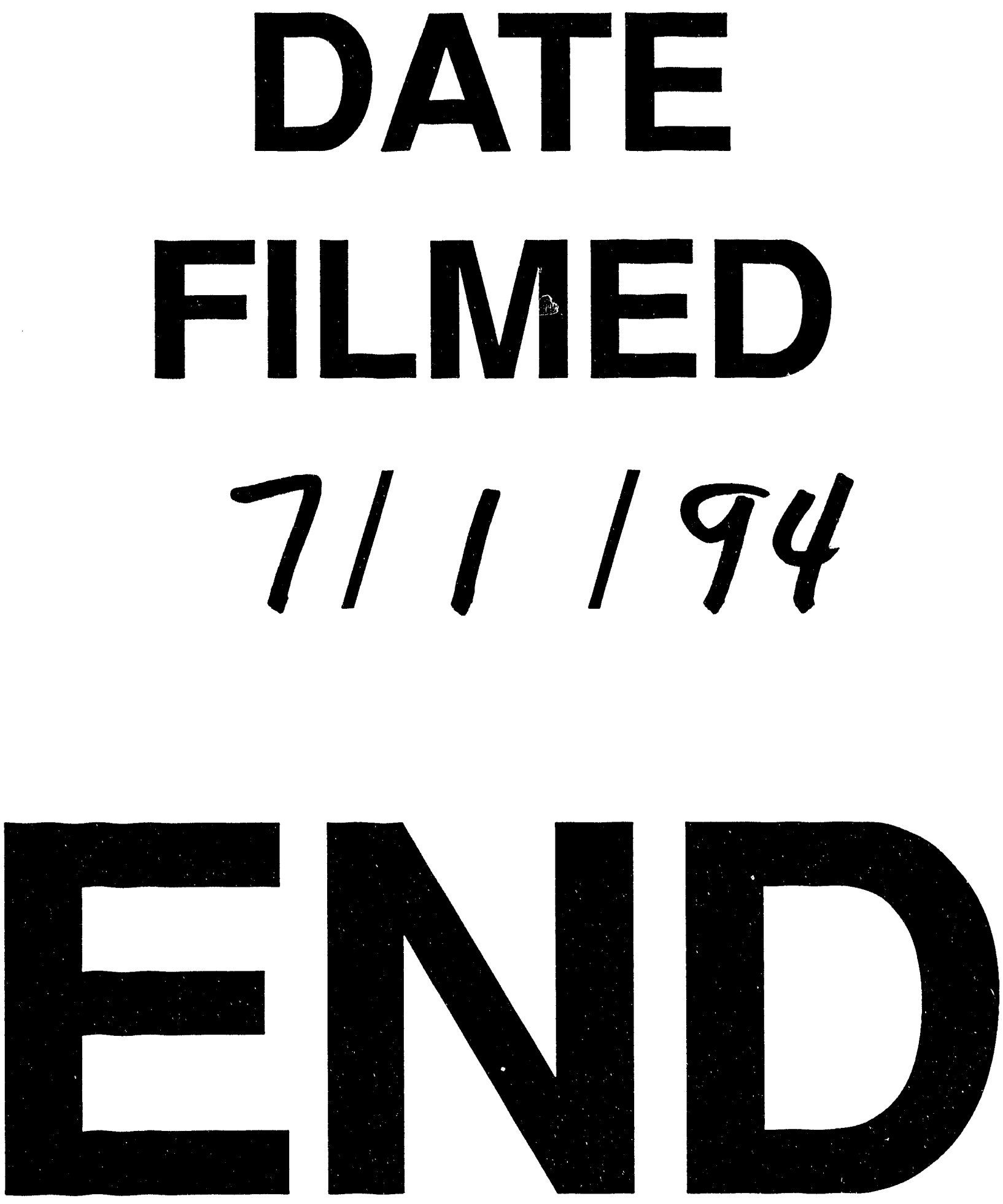


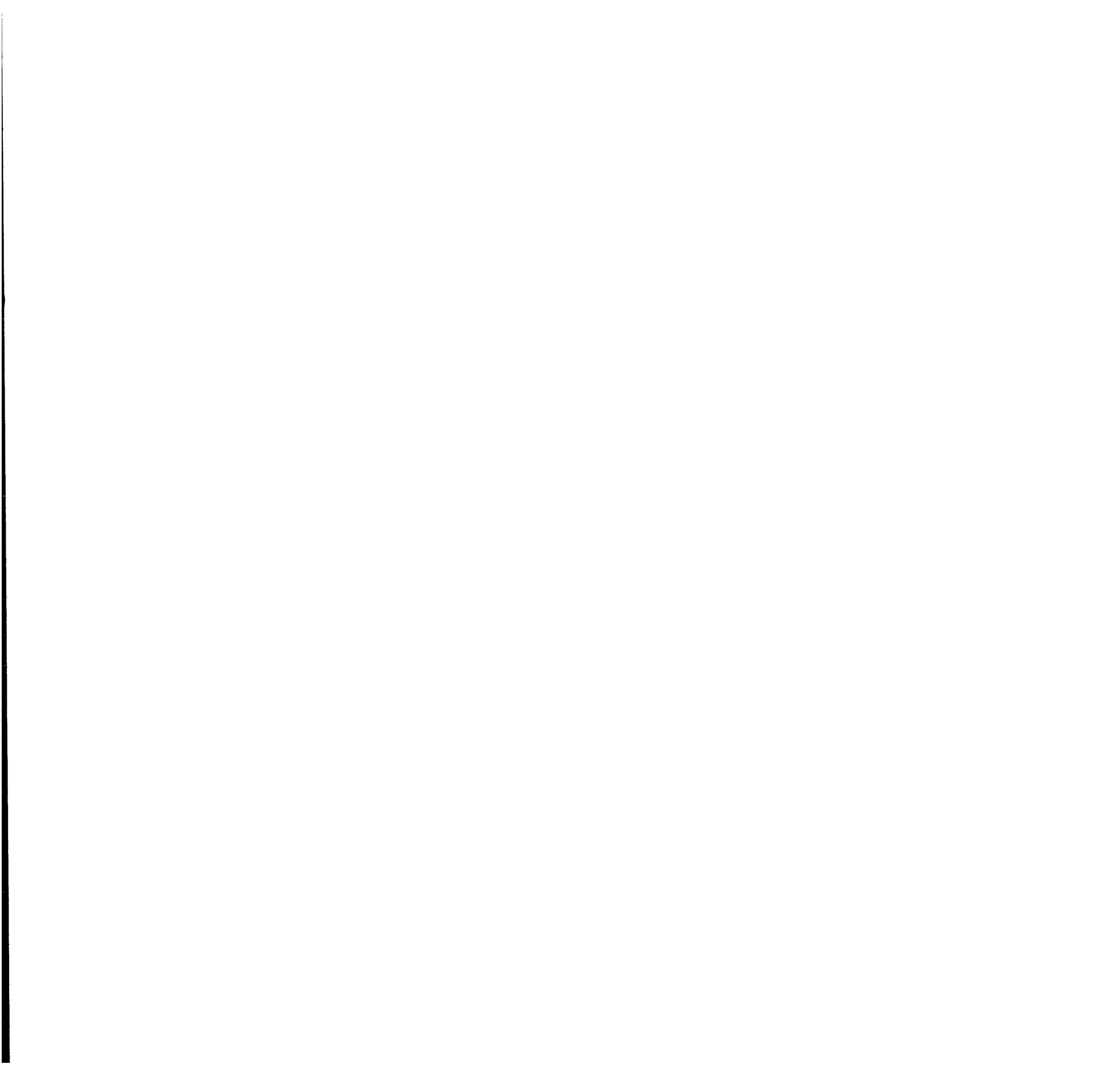

